\title{
Profil dan Potensi Pejantan Sapi Peranakan Ongole Penghasil Calon Galur Baru
}

\author{
(Profile and Potency of Ongole Cross Breed Bull \\ for Candidate of the New Strain Producer)
}

\author{
Aryogi, Adinata Y, Pamungkas D \\ Loka Penelitian Sapi Potong, Jl. Pahlawan No. 2, Grati, Pasuruan, Jawa Timur \\ yennysahim@gmail.com
}

\begin{abstract}
Increasing productivity of beef cattle can be done through the establishment of a new strain that has specific advantages, mating arrangement and selection to produce germ cattle and superior bull, also feeding that efficient at nutrients value. This research aimed to obtain specific profiles and potential of Ongole Cross Breed (OCB) bull at Indonesian Beef Cattle Research Station (IBCRS) as producing a new strain of OCB candidate, particularly related to the BUSS (new, superior, uniform and stable) criteria. Eleven heads of OCB bull as the best of F3 at IBCRS, observed its specific phenotype profile and potential productivity, from birth until become as active bull in feeding on lower crude protein $(8-11 \%)$ and high crude fiber $(22-26 \%)$ content. The data were presented descriptively. The results showed that profile of bull as producer of OCB new strain candidates, has BUSS requirements; superior production potential in body weight and high hump from birth to adulthood; the potential for superior reproduction in libido, quantity and quality of sperm. Conclusion, OCB bull in IBCRS that have been selected and prepared as elder candidates for formation a new strain of $\mathrm{OCB}$, which pedigree and criteria have qualified as bull to produce F4 of OCB new strain.
\end{abstract}

Key Words: Profile, Potential, New Strains, OCB

\begin{abstract}
ABSTRAK
Peningkatan produktivitas sapi potong dapat dilakukan melalui pembentukan galur baru yang mempunyai sifat keunggulan spesifik, pengaturan perkawinan dan seleksi untuk menghasilkan sapi bibit dan pejantan unggul, serta pemberian pakan yang nilai nutriennya efisien. Tujuan penelitian ini mendapatkan profil dan potensi spesifik pejantan sapi PO di Lolitsapi sebagai penghasil calon galur baru sapi PO, khususnya terkait dengan kriteria baru, unggul, seragam dan stabil (BUSS). Sebanyak 11 ekor pejantan F3 terbaik di Lolitsapi, diamati profil fenotipe spesifiknya dan potensi produktivitasnya, sejak lahir sampai menjadi pejantan aktif pada pemberian ransum yang kandungan protein kasarnya rendah (8-11\%) dan serat kasarnya tinggi (22-26\%). Data disajikan secara deskriptif. Hasil penelitian menunjukkan profil pejantan calon penghasil galur baru sapi PO telah memenuhi persyaratan BUSS, potensi produksinya unggul dalam hal berat badan dan tinggi gumba sejak lahir sampai dewasa, potensi reproduksinya unggul pada libido, kuantitas dan kualitas spermanya. Disimpulkan bahwa sapi PO pejantan di Lolitsapi yang telah dipilih dan disiapkan sebagai calon tetua pembentukan galur baru sapi PO, secara silsilah dan kriteria telah memenuhi persyaratan sebagai pejantan untuk menghasilkan F4 galur baru sapi PO.
\end{abstract}

Kata Kunci: Profil, Potensi, Galur Baru, PO

\section{PENDAHULUAN}

Peningkatan produktivitas sapi potong dapat dilakukan melalui perbaikan genetik sapi (Sutarno \& Setyawan 2016), seperti pembentukan galur dan rumpun baru yang mempunyai sifat keunggulan spesifik, serta pengaturan perkawinan dan seleksi untuk menghasilkan 
sapi bibit dan sapi pejantan unggul, juga dapat melalui perbaikan tatalaksana pemeliharaan seperti pemberian pakan yang nilai nutriennya efisien.

Loka Penelitian Sapi Potong (Lolitsapi) mulai melakukan kegiatan pembibitan sapi PO sejak tahun 2002 (diawali dengan melakukan penjaringan sapi PO dari peternak rakyat di Jawa Timur dan Jawa Tengah) dan tetap berlangsung sampai sekarang; bertujuan utama menghasilkan calon pejantan sapi PO terseleksi, melalui pemberian ransum yang kandungan protein kasarnya rendah (8-11\%), serat kasarnya tinggi (22-26\%) dan disusun dari hasil samping produk pertanian.

Mariyono et al. (2014) melaporkan hasil penelitiannya, sapi PO muda (umur 16-23 bulan) di Lolitsapi mempunyai nilai efisiensi pemanfaatan nutrien pakan yang tidak berbeda nyata pada kualitas pakan dengan kandungan SK mulai 12-27\%, karena nilai kecernaan semu nutrien pakannya (BK, PK, LK, SK, BO, TDN, SDA dan SDN) tidak berbeda pada perbedaan kandungan SK pakan tersebut. Hasil penelitian Anggraeny et al. (2014) menunjukkan bahwa sapi PO lepas sapih di Lolitsapi yang diberi pakan dengan kandungan protein kasar hanya 9,64-9,68\%, mampu mensuplai protein kasar asal mikroba rumen sebesar 31,3-32,8 g N/kg BOTR, sementara hasil penelitian Hindratiningrum et al. (2011) pada sapi PO umur 1-2 tahun di tempat lain yang diberi pakan dengan kandungan protein kasar ransum antara 10,43-10,94\%, hanya mampu mensuplai protein kasar asal mikroba rumen sebesar 24,74-34,37 g N/kg BOTR. Berdasarkan hal tersebut, maka kemampuan memanfaatkan pakan berkualitas rendah perlu menjadi salah satu kriteria dalam seleksi sapi potong.

Sampai akhir tahun 2016, sapi-sapi PO di Lolitsapi yang dewasa sudah merupakan generasi ketiga (F3) yang lahir, tumbuh dan berkembang dengan pemberian ransum tersebut, sehingga berdasarkan hasil penelitian Mariyono et al. (2014) dan Anggraeny et al. (2014) di atas, maka F3 sapi-sapi PO di Lolitsapi telah terbentuk suasana fisik, kimiawi dan mikrobiologis di saluran dan organ pencernaan yang spesifik mampu mencerna dan menyerap ransum berkualitas rendah (Aryogi et al. 2016). Pejantan sapi PO yang akan menjadi penghasil calon galur baru tersebut, diduga mempunyai profil dan potensi yang Baru, Unggul, Seragam dan Stabil (BUSS), berbeda dengan sapi PO lainnya.

Permentan Nomor: 19/Permentan/OT.140/2/2008 tentang Penetapan dan Pelepasan Rumpun atau Galur Ternak, antara lain menyebutkan: yang dimaksud dengan "galur" adalah sekelompok individu ternak dalam satu rumpun yang dikembangkan untuk tujuan pemuliaan dan/atau karakteristik tertentu; pelepasan rumpun atau galur ternak adalah pengakuan pemerintah terhadap suatu rumpun atau galur ternak unggul hasil pemuliaan atau introduksi yang dapat disebarluaskan; permohonan pelepasan, antara lain dapat dilakukan oleh lembaga penelitian dan pengembangan. Oleh karena itu, sebagian pejantan sapi PO yang saat ini ada di Lolitsapi merupakan sapi generasi keempat (F4) untuk dapat dicalonkan sebagai galur baru sapi PO yang spesifik mampu mencerna ransum berprotein rendah dan berserat tinggi, sehingga adaptif dibudidayakan di daerah marjinal/lahan kering

Penelitian ini bertujuan mendapatkan profil dan potensi spesifik dari pejantan sapi PO di Lolitsapi yang akan menghasilkan calon galur baru sapi PO, khususnya terkait dengan kriteria BUSS (baru, unggul, seragam dan stabil).

\section{MATERI DAN METODE}

Penelitian dilakukan dari tahun 2012 sampai tahun 2016, merupakan bagian dari tahapan akhir serangkaian pembentukan galur baru (Skema 1), yaitu sejak sapi generasi ketiga (F3) lahir sampai terpilih sebagai pejantan untuk menghasilkan generasi ke empat (F4). Data profil dan potensi pejantan sapi PO penghasil calon galur baru ini, berupa data pertumbuhan dan perkembangan sejak lahir sampai menjadi pejantan, dari 11 sapi F3 
terbaik hasil seleksi yang dikembangbiakkan Lolitsapi dengan pemberian pakan berkualitas rendah (protein kasar 8 s.d. 11\%; serat kasar 22 s.d. 26\%; TDN 55 s.d. 57\%; lemak kasar kurang dari $6 \%$ dan bahan organik di atas 87\%), konsumsi bahan kering minimal sebanyak $3 \%$ berat badan, serta manajemen pemeliharaan menggunakan Kandang Kelompok Model Litbangtan.

\begin{tabular}{|c|c|c|}
\hline Tahun & Generasi & Pengaturan perkawinan \\
\hline 2002 & & Penjaringan sapi PO dari Jatim dan Jateng \\
\hline $2003 / 2004$ & & 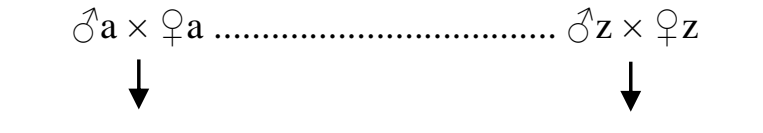 \\
\hline $2004 / 2005$ & F1: & ô $/ q$ \\
\hline $2007 / 2008$ & & 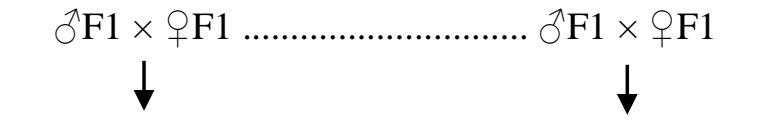 \\
\hline $2008 / 2009$ & F2: & $0 / q$ \\
\hline $2012 / 2013$ & & $\begin{array}{c}\partial^{\top} \mathrm{F} 2 \times{ }_{q} \mathrm{~F} 2 \\
\downarrow\end{array}$ \\
\hline $2013 / 2014$ & F3: & $\delta / 9$ \\
\hline $2016 / 2017$ & & $\begin{array}{c}{ }^{\lambda} \mathrm{F} 3 \\
\downarrow\end{array}$ \\
\hline $2017 / 2018$ & F4: & $\delta / q$ \\
\hline $2018 / 2019$ & & Galur baru sapi PO terseleksi: $\mathrm{F} 4$ umur $\geq 8$ bulan \\
\hline
\end{tabular}

Skema 1. Alur pembentukan pejantan calon penghasil galur baru sapi PO

Ke-11 pejantan F3 terbaik ini, diperoleh dari hasil seleksi dan pengaturan perkawinan sejak F1, terhadap sapi-sapi tetuanya yang ada di kelompok populasi dasar. Jumlah dan performa produksi sapi setiap generasi di kelompok dasar disajikan pada Tabel 1. 
Tabel 1. Jumlah tetua dan karakteristik performa sapi pejantan terpilih di setiap generasi

\begin{tabular}{lccc}
\hline Keterangan & F1 & F2 & F3 \\
\hline $\begin{array}{l}\text { Jumlah sapi pejantan } \\
\text { (ekor) }\end{array}$ & 10 & 21 & 51 \\
$\begin{array}{l}\text { Jumlah sapi indukan } \\
\text { (ekor) }\end{array}$ & 59 & 93 & 245 \\
Berat lahir (kg) & $21,9 \pm 3,1$ & $23,6 \pm 2,22$ & $2,5 \pm 2,9$ \\
Berat sapih umur & $114,4 \pm 17,6$ & $124,3 \pm 27,0$ & $129,2 \pm 30,1$ \\
$\begin{array}{l}205 \text { hari (kg) } \\
\text { Berat badan umur }\end{array}$ & $122,4 \pm 20,9$ & $132,8 \pm 19,8$ & $164,7 \pm 39,7$ \\
12 bulan (kg) & $156,3 \pm 21,8$ & $172,3 \pm 33,9$ & $227,1 \pm 49,3$ \\
$\begin{array}{l}\text { Berat badan umur } \\
18 \text { bulan (kg) }\end{array}$ & $206,8 \pm 23,1$ & $221,3 \pm 24,4$ & $291,7 \pm 62,4$ \\
$\begin{array}{l}\text { Berat badan umur } \\
24 \text { bulan (kg) }\end{array}$ & $135,6 \pm 1,5$ & $138,7 \pm 3,3$ & $142,3 \pm 4,2$ \\
$\begin{array}{l}\text { Tinggi gumba umur } \\
24 \text { bulan (cm) }\end{array}$ & & & \\
\hline
\end{tabular}

Parameter yang diamati meliputi: (1) Profil eksterior badan yang spesifik: Tanduk, moncong, gumba, gelambir dan pantat; (2) Potensi produksi saat: lahir, sapih, umur 12 dan 24 bulan; Data yang diperoleh ditabulasi dan disajikan secara deskriptif

\section{HASIL DAN PEMBAHASAN}

\section{Profil eksterior badan (fenotipik) spesifik}

Secara umum, eksterior badan sapi pejantan penghasil calon galur baru sapi PO adalah hampir sama dan sekilas agak sulit dibedakan dengan sapi PO yang ada di masyarakat. Namun demikian, terdapat beberapa ciri spesifik di badannya yang lebih cenderung ke sapi Ongole dibandingkan dengan sapi Brahman dan sapi PO lainnya (Gambar 1). Kepala mengarah ke bentuk pooled, yaitu kepala dengan tanduk yang sangat pendek tetapi besar dan arah tumbuhnya ke samping. Ciri ini lebih kuat mengarah ke sapi Brahman, yaitu kepala dengan tanduk yang tumbuh pendek tetapi besar dan mengarah ke samping belakang, sementara ciri umum kepala sapi Ongole adalah bertanduk cukup panjang tetapi tidak terlalu besar dan arah tumbuhnya ke samping atas (Anonimus 2015).

Ujung hidung hampir selalu berwarna hitam, hal ini menunjukkan kuatnya pengaruh sapi Brahman, karena pada sapi Ongole masih sering dijumpai warna coklat muda dan merah kekuningan (Sudrajad et al. 2013). Gumba/kelasa/punuk yang pendek, bundar dan tumbuh mengarah ke atas, cenderung mengarah ke ciri sapi Ongole, karena pada sapi Brahman adalah panjang/tinggi, bentuk lonjong dan tumbuh mengarah ke atas belakang. Gelambirnya yang mempunyai lipatan-lipatan sempit tetapi lebih banyak masih menunjukkan kuatnya pengaruh sapi Ongole, karena pada sapi Brahman adalah lebar sehingga hanya ada beberapa lipatan. Bentuk pantat yang runcing juga cenderung mencirikan sapi Ongole (Sudrajad et al. 2013), karena sapi Brahman cenderung berbentuk persegi (Anonimus 2015).

Perbedaan profil eksterior pada pejantan calon penghasil galur baru sapi PO ini belum dapat diketahui apa pengaruh dan bagaimana hubungan langsungnya terhadap profil dan potensi produktivitas sapinya. Namun tampak bahwa profil eksterior pejantan calon penghasil galur baru sapi PO ini cenderung mengarah ke kuatnya ciri sapi Ongole, dibandingkan dengan sapi PO maupun sapi Brahman. Hal ini diduga tejadi, karena 
tindakan seleksi dan perkawinan tertutup (tidak ada darah/sapi baru yang masuk), serta manajemen pemeliharaan yang sama selama 14 tahun (2002/2003 - 2016/2017) terhadap sapi-sapi yang ada di Lolitsapi, telah menyebabkan terjadinya peningkatan persentase genetik sapi Ongole dan penurunan persentase genetik sapi Brahman maupun sapi lainnya yang membentuk sapi Peranakan Ongole.

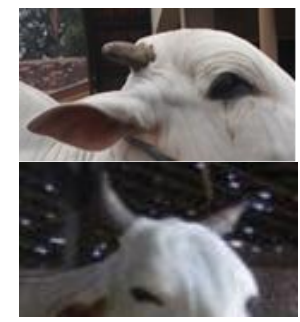

Kepala

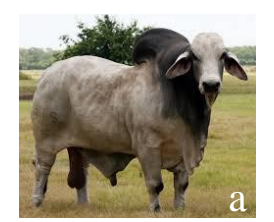

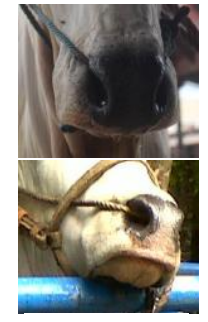

Hidung

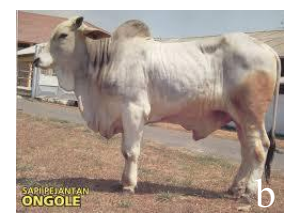

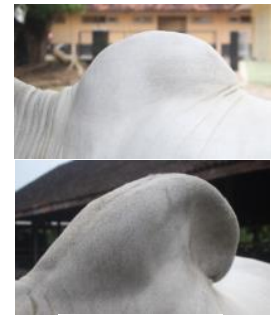

Gumba

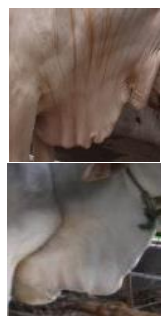

Gelambir

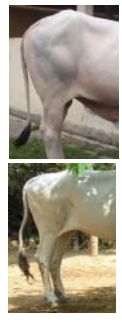

Pantat
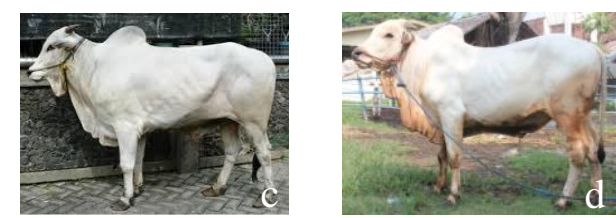

Gambar 1. Perbedaan eksterior bagian-bagian badan antara calon galur baru sapi PO terseleksi (atas) dengan sapi PO lainnya (tengah), serta perbedaan fenotipe (bawah) antara: (a) sapi Brahman, (b) sapi Ongole, (c) sapi PO dan (d) sapi calon galur baru sapi PO

Sumber: ${ }^{\mathrm{a}, \mathrm{b}, \mathrm{c}}$ Anonimus (2017); ${ }^{\mathrm{d}}$ Lolitsapi

\section{Potensi produksi}

\section{Lahir sampai sapih}

Pejantan-pejantan sapi PO calon penghasil galur baru, ketika lahir mempunyai ratarata performa berat lahir dan tinggi gumba $26,8 \pm 2,5 \mathrm{~kg}$ dan $75,8 \pm 4,1 \mathrm{~cm}$. Rata-rata berat lahir pedet sapi PO adalah 22,1 kg (Wardoyo \& Risdianto 2011) dengan tinggi gumba 73,7 $\mathrm{cm}$ (Ferdianto et al. 2013). Tampak bahwa di samping unggul dalam hal berat lahir dan tinggi gumba dibandingkan dengan pedet PO yang ada di peternak, juga nilai standar deviasinya sudah cukup rendah (keseragamannya mulai tinggi/keanekaragamannya mulai rendah), yaitu masing-masing 9,5 dan 5,4\%. Sementara itu saat mencapai umur sapih 205 hari, pejantan-pejantan sapi PO calon penghasil galur baru ini mempunyai performa berat badan dan tinggi gumba masing-masing $111,4 \pm 15,7 \mathrm{~kg}$ dan $100,4 \pm 6,4 \mathrm{~cm}$, yaitu lebih tinggi dibanding hasil penelitian Ferdianto, et al. (2013) yang melaporkan rata-ratanya sebesar 106,5 $\mathrm{kg}$ dan $98,3 \mathrm{~cm}$.

\section{Umur 12 dan 24 bulan}

Ketika mencapai umur 12 dan 24 bulan, pejantan-pejantan calon penghasil galur baru sapi PO mampu mencapai berat badan dan tinggi gumba masing-masing 189,0 $\pm 12,7 \mathrm{~kg}$ dan $115,7 \pm 4,5 \mathrm{~cm}$ serta $369,4 \pm 25,8 \mathrm{~kg}$ dan $134,3 \pm 3,2 \mathrm{~cm}$. Kemampuan mencapai tinggi gumba tersebut, adalah di atas persyaratan minimal yang telah ditetapkan SNI 2015 untuk bibit sapi PO jantan klas I yang hanya $128 \mathrm{~cm}$ (umur 18-24 bulan) dan $133 \mathrm{~cm}$ (umur >2436 bulan). 


\section{Calon pejantan, pejantan terpilih dan pejantan aktif}

Pejantan-pejantan calon penghasil galur baru sapi PO ketika terpilih menjadi calon pejantan (umur 18-24 bulan) mampu mencapai berat badan dan tinggi gumba masingmasing $297,5 \pm 6,9 \mathrm{~kg}$ dan $123,6 \pm 4,2 \mathrm{~cm}$; pejantan muda (mulai umur 24 bulan) mampu mencapai berat badan dan tinggi gumba $395,5 \pm 5,7 \mathrm{~kg}$ dan $137,6 \pm 4,2 \mathrm{~cm}$; serta pejantan aktif mampu mencapai berat badan dan tinggi gumba 564,5 $\pm 26,9 \mathrm{~kg}$ dan $147,6 \pm 2,3 \mathrm{~cm}$. Pejantan sapi PO terpilih calon penghasil galur baru ini, ketika telah aktif sebagai pejantan, tampak mempunyai tinggi gumba yang jauh di atas SNI 2015 untuk bibit sapi PO.

\section{Potensi reproduksi}

Potensi reproduksi pejantan calon penghasil galur baru sapi PO, diamati melalui libido serta kuantitas dan kualitas spermanya (Tabel 3).

Tabel 3. Libido serta kuantitas dan kualitas sperma pejantan aktif calon penghasil galur baru sapi PO

\begin{tabular}{lc}
\hline Keterangan & Hasil pengamatan \\
\hline 1. Libido (menit) & $6,5 \pm 1,2$ \\
2. Kuantitas : volume $(\mathrm{ml})$ & $2,6 \pm 0,9$ \\
3. Kualitas : Konsentrasi $\left(\times 10^{9} / \mathrm{ml}\right)$ & $2,1 \pm 0,4$ \\
$:$ pH & $7,0 \pm 0,2$ \\
$:$ Gerakan massa & ++ sampai +++ \\
: Motilitas $(\%)$ & $82,7 \pm 1,3$ \\
: Sperma hidup (\%) & $85,9 \pm 2,7$ \\
: Sperma abnormal $(\%)$ & $10,3 \pm 9,5$ \\
\hline
\end{tabular}

Hedah (1992) menyatakan bahwa kualitas semen yang memenuhi standar diproses untuk menjadi semen beku adalah motilitas lebih dari 70\%, $\mathrm{pH} 4-7$, konsentrasi sperma $1.025 \times 10^{6} / \mathrm{ml}$. Tampak bahwa kuantitas dan kualitas sperma pejantan adalah baik dan memenuhi persyaratan seandainya akan diolah dan dimanfaatkan sebagai sumber semen pada pembuatan semen beku maupun semen cair. Kesebelas pejantan calon penghasil galur baru sapi PO ini telah dikawinkan dengan 184 induk sapi PO (satu pejantan dikawinkan dengan 15-20 indukan dalam waktu 60 hari), hasilnya adalah sampai akhir bulan Desember 2016 telah lahir 163 pedet, dimana 48 pedet diantaranya telah lepas sapih umur 205 hari.

\section{Kriteria BUSS}

Berdasarkan potensi produksi dan potensi reproduksi di atas, menunjukkan bahwa pejantan calon penghasil galur baru sapi PO yang ada di Lolitsapi, telah memenuhi beberapa persyaratan BUSS (baru, unggul, stabil, seragam) sehingga berpotensi untuk diusulkan sebagai calon penghasil galur baru sapi PO. Persyaratan BUSS tersebut adalah sebagai berikut:

a. BARU. Setelah mencapai F3 atau lebih 10 tahun dibentuk melalui tatalaksana pemeliharaan model Lolitsapi (kualitas dan bahan penyusun pakan, serta model perkandangan) yang tidak pernah berubah, serta pengaturan perkawinan secara tertutup (antar sapi yang sudah ada) dan seleksi mengarah hanya ke satu sifat genetik (tinggi gumba $135 \mathrm{~cm}$ mulai umur 24 bulan), maka sapi PO yang ada di Lolitsapi diduga telah membentuk fenotipik yang mengarah ke beberapa ciri khas baru. 
b. UNGGUL. Melalui budidaya dan pengembangan model Lolitsapi, pejantan penghasil calon galur baru sapi PO ini mempunyai sejarah keunggulan produktivitas (produksi dan reproduksi) yang telah teruji dan di atas standar SNI Sapi PO tahun 2015.

c. STABIL. Performa produksi, reproduksi maupun tampilan badan luar (fenotipik) spesifik dari pejantan sapi PO calon penghasil galur baru ini, sudah mulai terbentuk sejak F2 dan hampir tidak mengalami perubahan yang signifikan di F3.

d. SERAGAM. Disamping stabil performa produksi, reproduksi maupun tampilan badan luar (fenotipik) spesifik dari pejantan sapi PO calon penghasil galur baru ini, juga menunjukkan keseragaman yang cukup tinggi, yaitu diperlihatkan dengan angka standar deviasi yang kecil. Detail keseragaman performa produksi, reproduksi dan fenotipe, akan disajikan pada tulisan lain.

\section{KESIMPULAN}

Sapi PO pejantan di Lolitsapi yang telah dipilih dan disiapkan sebagai calon tetua pembentukan galur baru sapi PO, secara silsilah dan kriteria telah memenuhi persyaratan sebagai pejantan untuk menghasilkan F4 galur baru sapi PO.

\section{DAFTAR PUSTAKA}

Anonimus. 2017. Karakteristik dan jenis sapi potong. Berbagi Ilmu Peternakan. https://dodymisa.blogspot.co.id/2015/05/karakteristik-dan-jenis-sapi-potong.html.

Anggraeny YN. 2014. Sinkronisasi Pasok Protein dan Energi Terhadap Proses Metabolisme Pakan Pada Sapi PO Lepas Sapih. [Disertasi S3]. Malang (Indonesia): Universitas Brawijaya.

Anonimus. 2015. Brahman cattle. Breed of livestock, Department of Animal Science. Oklahoma State University. [Internet]. Available at http://www.ansi.okstate.edu/breeds/cattle/brahman/.

Anonimus. 2015. SNI 7651.5 : 2015. Bibit sapi potong - Bagian 5 : Peranakan Ongole. Jakarta (Indonesia): Badan Standardisasi Nasional.

Aryogi, Adinata Y, Pamungkas D, Rasyid A, Luthfi M, Sukmasari PK, Adjid A, Hartati. 2016. Pembentukan galur baru sapi PO Agrinak. Laporan Akhir 2016. Grati (Indonesia): Lolitsapi.

Ferdianto N, Soejosopoetro B, Maylinda S. 2013. Birth weight, weaning weight and linear body measurement of Ongole Cross cattle at two group parities. Faculty of Animal Husbandry, University of Brawijaya, Malang. [Internet]. Available at http://fapet.ub.ac.id/wpcontent/uploads/2013/04/.

Hedah D. 1992. Peranan Balai Inseminasi Buatan Singosari dalam meningkatkan mutu sapi Madura melalui inseminasi buatan. Prosiding Pertemuan Ilmiah Hasil Penelitian dan Pengembangan Sapi Madura. Grati (Indonesia): Sub Balitnak. hlm. 92-100.

Hindratiningrum N, Bata M, Santosa SA. 2011. Produk fermentasi rumen dan produksi protein mikroba sapi lokal yang diberi pakan jerami amoniasi dan beberapa bahan pakan sumber energi. Agripet. 11:29-34.

Kementan. 2006. Peraturan Menteri Pertanian Nomor 54/Permentan/OT.140/10/2006 Tentang Pedoman Pembibitan Sapi Potong Yang Baik (Good Breeding Practice). Jakarta (Indonesia): Kementerian Pertanian.

Mariyono, Rasyid A, Anggraeny YN, Krishna NH, Sulistya TA. 2014. Pakan sapi potong berbasis limbah pertanian dan perkebunan ramah lingkungan. Laporan Akhir TA 2014. Grati (Indonesia): Lolitsapi.

Sudrajad P, Subiharta, Adinata Y. 2013. Karakter fenotipik sapi betina Peranakan Ongole Kebumen. Dalam: Purwantari ND, Saepulloh M, Iskandar S, Anggraeni A, Ginting SP, 
Priyanti A, Wiedosari E, Yulistiani D, Inounu I, Bahri S, Puastuti P, penyunting. Inovasi Teknologi Peternakan dan Veteriner Berbasis Sumber Daya Lokal yang Adaptif dan Mitigatif terhadap Perubahan Iklim. Prosiding Seminar Nasional Teknologi Peternakan dan Veteriner. Medan, 3-5 September 2013. Jakarta (Indonesia): IAARD Press. hlm. 98-106.

Sutarno, Setyawan AD. 2016. The diversity of local cattle in Indonesia and the efforts to develop superior indigenous cattle breeds. Biodiversitas. 17:275-295.

Wardoyo, Risdianto A. 2011. Studi manajemen pembibitan dan pakan sapi Peranakan Ongole di Loka Penelitian Sapi Potong Grati Pasuruan. J Ternak. 2:1-7.

\section{DISKUSI}

\section{Pertanyaan}

Dalam hal apa kriteria seleksi dilakukan?

\section{Jawaban}

Seleksi pada tinggi gumba dengan memperhatikan SNI, untuk seleksi yang cepat. 